\title{
Profesionalisme Pegawai Ditinjau Dari Aspek Pengorganisasian Dalam Pelayanan Publik
}

\author{
${ }^{1}$ Abdul Wahab Podungge, ${ }^{2}$ Asna Aneta \\ ${ }^{1}$ Program Studi Administrasi Publik,Universitas Gorontalo \\ Gorontalo, Indonesia, 96211 \\ ${ }^{2}$ Program Studi Administrasi Publik,Universitas Negeri Gorontalo \\ Gorontalo, Indonesia, 96218 \\ E-mail: Podunggewahab@gmail.com ; asnaatiek.aneta@gmail.com
}

Received: 13 Februari 2020; Revised: 17 Maret 2020; Accepted: 26 April 2020

\begin{abstract}
This article aims to analyze: Employee professionalism in terms of organizational aspects in publik services. The method used in this article is a qualitative method. The results of the article show that the tendency of apparatus to be less professional in carrying out their duties and functions is partly due to the low motivation to make changes and innovate. The apparatus tends to be reluctant to make changes due to a lack of encouragement from the leadership. In realizing a professional, accountable, and transparent apparatus, it requires a leader role as a guide and has a visionary spirit and vision in the Gorontalo City One Stop Integrated Services and Investment Service. Concrete steps for leaders in creating a democratic climate where subordinates are included in every policy making related to improving organizational performance and building two-way communication in every activity will make subordinates feel that they are an important part of the organization. The attitude of the leader to foster a responsive spirit in every employee can improve the quality of licensing and non-licensing services in Gorontalo City. Efforts that can be made to foster the professionalism of the personnel are by making long-term, medium-term and short-term work programs and setting priority scales in every activity aimed at improving the quality of publik services.
\end{abstract}

Keywords: Professionalism; Management; Bureaucracy

\begin{abstract}
Abstrak
Artikel ini bertujuan untuk menganalisis tentang profesionalisme pegawai ditinjau dari aspek pengorganisasian dalam pelayanan publik. Metode yang digunakan dalam artikel ini yakni metode kualitatif. Hasil artikel menunjukan bahwa kecenderungan aparat kurang profesional dalam menjalankan tugas dan fungsinya antara lain disebabkan oleh rendahnya motivasi untuk melakukan perubahan dan berinovasi. Aparat cenderung enggan melakukan perubahan dikenakan kurangnya dorongan dari pimpinan. Dalam mewujudkan aparat yang profesional, akuntabel, dan transparan maka dibutuhkan peran pemimpin sebagai pengarah dan memiliki jiwa dan pandangan yang visioner pada Dinas Penanaman Modal Dan Pelayanan Terpadu Satu Pintu Kota Gorontalo. Langkah-langkah konkrit pemimpin dalam menciptakan iklim demokrasi dimana bawahan disertakan dalam setiap pengambilan kebijakan yang berkaitan dengan peningkatan kinerja organisasi serta membangun komunikasi dua arah dalam setiap kegiatan akan membuat bawahan merasa dirinya adalah bagian penting dalam organisasi. Sikap pemimpin untuk menumbuhkan jiwa responsif pada setiap pegawai dapat meningkatan kualitas pelayanan perizinan dan non perizinan di Kota Gorontalo. Upaya yang dapat dilakukan untuk menumbuhkan profesionalisme aparatur adalah dengan membuat program kerja jangka Panjang, jangka menengah, dan jangka pendek serta menetapkan skala prioritas dalam setiap kegiatan yang bertujuan meningkatkan kualitas pelayanan publik.
\end{abstract}

Kata Kunci : Profesionalisme; Manajeman; Birokrasi

Link DOI : http://dx.doi.org/10.31314/pjia.9.1.55-65.2020 


\section{PENDAHULUAN}

Keberhasilan pemerintah daerah dalam menangani setiap permasalahannya salah satunya dapat diukur melalui keberhasilan pelayanan yang dilakukan oleh pemerintah itu sendiri. Layanan publik yang merupakan seluruh rangkaian kegiatan dalam rangka pemenuhan kebutuhan dasar sesuai dengan hak-hak dasar setiap warga negara dan penduduk atas suatu ketetapan barang, jasa, dan pelayanan administrasi yang disediakan oleh penyelenggara pelayanan terkait dengan kepentingan publik. Penyelenggara pelayanan publik yang dimaksud adalah birokrat/pegawai atau tenaga honorer yang berkecimpung dalam lingkaran pemerintahan untuk selanjutnya memanfaatkan kewenangan dan tanggung jawab yang diberikan masyarakat kepada mereka dalam menentukan arah kebijakan bagi pembangunan daerah secara berkesinambungan dan konsisten.

Permasalahan birokrasi kita saat ini diantaranya terlalu banyak biro (meja) yang harus dilewati dalam rangkaian proses pembuatan kebijakan publik yang dimaksud. Disisi lain dengan perkembangan teknologi informasi dan komunikasi yang saat ini sudah semakin canggih dan cepat menuntut adanya profesionalisme bagi tiap-tiap individu dalam bekerja, termasuk diantara pegawai dilingkungan pemerintahan. Pemerintah sebagai penyedia pelayanan mengatur proses dan tatacara pemberian pelayanan yang baik dengan sesuai standar yang sudah ditentukannya, yang dalam hal ini yakni maklumat pelayanan dan tingkatan operasional proses.

Dalam perspektif administrasi publik di Indonesia dikenal secamacam patologi yang membuat birokrat atau aparat tidak professional dalam menjalankan tugas dan fungsinya antara lain disebabkan oleh rendahnya motivasi untuk melakukan perubahan dan berinovasi. Patologi ini terjadi sebagai konsekuensi dari keseluruhan perilaku gaya manajerial yang sering digunakan oleh manajeman puncak (the strategic-apex) pada hierarki organisasi publik. Siagian (2002) menegaskan bahwa gaya manajerial yang bersifat feodalistik dan paterlistik berpengaruh besar terhadap kinerja organisasi sehingga jajaran birokrasi tingkat menengah dan bawah takut untuk melakukan dan mengambil langkahlangkah baru dalam upaya peningkatan kualitas pelayanan publik. Keadaan ini juga diperparah dengan rendahnya keinginan melakukan perubahan dan inovasi dalam hal ini juga disebabkan oleh gaya manajerial yang tidak kondusif untuk menciptakan iklim birokrasi yang responsif dan inovatif sehingga tidak mengherankan jika kemampuan kerja organisasi dan jajarannya menjadi rendah.

Profesionalisme mencerminkan sikap seseorang terhadap pekerjaan maupun jenis pekerjaannya. Moeljono

(2003) mengatakan bahwa profesionalisme terdiri dari tiga unsur, yaitu knowledge, skill, integrity, selanjutnya ketiga unsur tersebut harus dilandaskan oleh iman yang teguh, pandai bersyukur, serta kesediaan belajar terus menerus. Profesionalisme juga mencerminkan keandalan dalam pelaksanaan tugas sehingga terlaksana dengan mutu yang baik, cermat, prosedur yang mudah, serta waktu yang terpat dan diikuti oleh masyarakat.

Dalam kompetensi dan kualitas ASN memiliki pengaruh perubahan yang signifikan terhadap sistem birokrasi pemerintahan serta menghasilkan output yang bisa menjadi tata pemerintahan yang baik dan pengembangan pelayananan yang sangatlah berkualitas, sehingga dalam aspek yang ada di dalam pemerintah juga 
akan mengalami perubahan yang sangat baik yaitu dengan pola pikir, karakter, manajemen, dan sistem yang ada didalam birokrasi dan dalam aspek di luarnya dengan kepuasan masyarakat atau rakyat terhadap penerimaan pelayanannya.

Masalah integritas ASN dapat dilihat dari banyaknya perilaku menyimpang yang dilakukan oleh oknum ASN seperti korupsi, kolusi, dan nepotisme (KKN). Bahwa masalah kompetensi dapat dilihat dari tingkat Pendidikan mayoritas ASN yang masih rendah. Menurut Menpan RB dari total 4.476.999 PNS ASN 64\% diantaranya hanya bekerja sebagai petugas administrasi, oleh karenanya kinerja ASN dapat dilihat dari output dimana masih banyaknya keluhan masyarat atas lambatnya pelayanan publik. Masalah disiplin dapat dilihat dari masih adanya perbuatan oknum pegawai yang menyimpang dari peraturan dan ketentuan yang ada seperti netralitas PNS, yaitu adanya dugaan keterlibatan ASN dalam kampanye Calon Walikota dan Wakil Walikota Gorontalo pada tahun 2018. Hal tersebut bersesuaian dengan temuan Indonesian Corruption Watch yang menempatkan ASN sebagai aktor paling banyak terjerat kasus korupsi selang tahun 2010-2019. Setidaknya ada sekitar lebih dari 3.417 Aparatur Sipil Negara (ASN) yang ditetapkan sebagai tersangka kasus korupsi disejumlah daerah termasuk beberapa dari Kota Gorontalo.

Dalam budaya birokrasi yang peneliti amati, terdapat dampak dalam pelayanan, budaya tata cara yang sangat melekat yang ada didalam sistem pelayanan apa lagi didaerah seperti Gorontalo sangatlah kental dengan budaya kekeluargaannya. Aparatur DPM-PTSP Kota Gorontalo diharapkan memberikan layanan perizinan yang terorganisasi dengan baik dan se-efisien mungkin untuk masyarakat pemohon perizinan dan penanaman modal. Hal Copyright @ 2020, Publik (Jurnal Ilmu Administrasi), ISSN: 2301-573X (Print), ISSN: 2581-2084 (Online) tersebut sejalan dengan hasil penelitian yang dilakukan oleh Arief Jauhari (2015) yang dimuat dalam Jurnal Magister Akuntansi ISSN 2302-0164 yang menegaskan bahwa didalam birokrasi pada era revolusi industry 4.0, sangat penting untuk menerapkan layanan yang berbasis e-Government karena berhubungan dengan penerapan Good Governance, Reformasi Birokrasi, dan kinerja pegawai itu sendiri. Ketiga hal tersebut saling memiliki keterkaitan dalam rangka efektivitas dan efisiensi pelayanan. Letak perbedaannya dengan penelitian ini terdapat pada hasil atau output yang dihasilkan, jika artikel Arief Jauhari (2015) menekankan pada output yang berorientasi pada hasil yang semua sistem dalam birokrasi dimuat dalam bentuk layanan e-Government sedangkan artikel ini penulis menekankan pada aspek mekanisme internal yang harus dibenahi oleh lingkungan organisasi itu sendiri. Dinamika yang terlihat pada DPMPTSP Kota Gorontalo salah satunya pada Standar Operasional Prosedur (SOP) organisasi yang kurang jelas, dimana hanya terdapat tiga SOP perizinan dari total 92 jenis perizinan dan non perizinan yang dikelola DPM-PTSP. Oleh sebab itu harus ada pengeturan internal didalam organisasi DPM-PTSP sehingga dapat menggerakkan seluruh potensi dan kebijakan yang terdapat didalamnya. Penulis berharap adanya perubahan mental/perilaku aparatur sebagai model dalam mewujudkan reformasi birokrasi yang berkualitas sehingga dapat menunjang pelaksanaan pelayanan publik yang lebih baik dan memuaskan masyarakat khususnya di Kota Gorontalo.

Artikel ini bertujuan untuk menganalisis tentang: Profesionalisme pegawai ditinjau dari aspek pengorganisasian dalam pelayanan publik. 


\section{METODE PENELITIAN}

Metode penelitian yang digunakan yakni metode kualitatif dikarenakan aspek profesionalisme pegawai dapat diukur melalui wawancara langsung dua arah sehingga dapat tergambarkan mengapa profesionalisme aparatur dalam pelayanan publik cenderung kurang memuaskan masyarakat. Adapun yang menjadi alasan peneliti mengambil mengangkat permasalahan pada lokasi penelitian ini di karenakan pergerakan perekonomian di Kota Gorontalo bersumber dari sektor jasa. Kota Gorontalo bukan penghasil Sumber Daya Alam yang melimpah maka upaya satu-satunya untuk menggerakan potensi daerah adalah pada sektor Sumber Daya Manusia, dimana sektor jasa menjadi peluang terbesar untuk meraup Pendapatan Asli Daerah (PAD) terbanyak. Dengan melihat keadaan investor dari daerah lain yang mendirikan usaha di Kota Gorontalo dibandingkan pada Kabupaten lain di wilayah Provinsi Gorontalo maka peran DPM-PTSP Kota Gorontalo harus dimaksimalkan.

Sektor pariwisata di Kota Gorontalo juga merupakan salah satu sektor yang menjadi ikon daerah untuk menambah PAD, karena menjadi tempat kunjungan wisatawan baik wisatawan lokal maupun mancanegara sebagai lokasi destinasi yang perlu perhatian oleh pemerintah daerah dalam mengembangkannya. Destinasi pariwisata di Kota Gorontalo masih kurang, baik fasilitas maupun penataannya sehingga oleh pemerintah perlu juga kerja sama dengan peran swasta untuk pengembangannya. Peluang investasi pembangunan hotel berbintang, pendirian biro perjalanan wisata, penyediaan sarana hiburan, dan rekreasi serta pendirian sanggar seni budaya. Disamping itu banyak juga potensi pada sektor jasa juga berpusat di Kota Gorontalo misalnya dibidang Kesehatan dan Pendidikan.

Analisis data yang digunakan dalam penelitian kualitatif adalah analisis model interaktif yang terdiri dari tiga komponen analisis yakni: 1) Reduksi Data; 2) Penyajian Data; 3) Verifikasi Data dan Penarikan Kesimpulan. (Miles \& Huberman, 1992)

Informan kunci dalam artikel ini terdiri dari: 1) Pimpinan DPM-PTSP dari Kepala Dinas, Sekretaris Dinas, para Kepala Bidang, para Kepala Bagian, Para Staf, dan 2) Petugas front office, petugas back office, dan staf pegawai dilingkungan DPM-PTSP Kota Gorontalo; 3) Masyarakat umum pemohon perizinan

\section{HASIL DAN PEMBAHASAN}

Organisasi pemerintah layaknya organisasi pada umumnya menuntut adanya profesionalisme ASN sebagai kunci keberhasilan bagi penyelenggaraan pelayanan publik. Birokrasi dipandang merupakan jenis organisasi yang dirancang untuk menangani tugas-tugas adminstratif dalam skala besar serta mengkoordinasikan pekerjaan orang banyak secara sistematis. Birokrasi juga dipandang sebagai mesin kerja pemerintah karena posisi birokrasi yang sangat pendng tersebut menjadikan birokrasi disorot dalam kinerjanya dan dituntut professional dalam mewujudkan keberhasilan bagi proses penyelenggaraan pelayanan publik.

Berdasarkan Peraturan Presiden Nomor 81 Tahun 2010 tentang Grand Design Reformasi Birokrasi 2010-2025 dan Peraturan Menpan RB Nomor 11 Tahun 2015 Tentang Road Map Reformasi Birokrasi 2015-2019 serta peraturan pelaksana lainnya, pemerintah berusaha menjawab permasalahan pemerintahan yang belum bersih, kurang akuntabel, dan 
Publik (Jurnal Ilmu Administrasi) Vol 9 (1), Juni 2020

berkinerja rendah. Hal tersebut ditegaskan dalam sasaran Reformasi Birokrasi 20152019 bahwa: 1) Birokrasi yang bersih dan akuntabel; 2) Birokrasi yang efektif dan efisien; 3) Birokrasi yang memiliki pelayanan publik yang berkualitas. Oleh karena itu peneliti berharap profesionalitas pegawai perlu dikembangkan dan menjadi perhatian khusus bagi pemerintah. Isu negatif terhadap profesionalisme khususnya jika dipandang dari aspek pengorganisasian manajeman pelayanan publik perlu direspon positif dengan terus melakukan evaluasi secara berkala baik itu evaluasi harian, mingguan, sampai dengan bulanan yang sering diterapkan pada organisasi sektor privat. Hal ini sejalan dengan hasil penelitian yang dilakukan oleh Henny Juliani yang dimuat dalam Jurnal Administrative Law \& Governance Vol. 2 No. 1 April 2019 (ISSN. 2621-2781) yang mengatakan bahwa pemerintah perlu mengambil langkah strategis membangun SDM aparatur melalui kebijakan reformasi birokrasi dengan inti perubahan pada mental/perilaku aparatur dan seluruh sistim yang melingkup aparatur. Fokus perubahan reformasi birokrasi tersebut diharapkan dapat menciptakan birokrasi yang bersih, akuntabel, efektf, efisien, serta mampu memberikan pelayanan publik yang berkualitas.

Berbeda dengan pendekatan manajeman birokrasi yang diungkapkan oleh Henny diatas, penulis melihat dengan pandangan lain yakni pendekatan pengorganisasian manajeman birokrasi untuk mengukur tingkat kepuasan masyarakat terhadap layanan perizinan dan non perizinan yang diselenggarakan oleh DPM-PTSP Kota Gorontalo. Peneliti menilai bahwa proses pengorganisasian dalam tubuh birokrasi yang bergerak dibidang pelayanan publik harus diukur dengan indicator sebagai berikut:
1) Pembagian kerja yang efisien; 2) Meningkatkan efektifitas kerja; 3) Pelayanan sesuai SOP. Penulis menemukan bahwa didalam proses pengorganisasian layanan penanaman modal dan perizinan sudah dilaksanakan sesuai dengan ketetapan komponen SOP (Standar Operasional Prosedur) yang rujukan regulasinya sudah sesuai dengan hierarki peraturan-perundangan yang berlaku dimana ketetapan waktu layanan menjadi hal yang paling menjadi prioritas pegawai. Akan tetapi penulis melihat hal ini masih kurang maksimal dijalankan karena berbagai alasan teknis yakni keterbatasan institusional DPM-PTSP dalam mengelola seluruh layanan perizinan dan non perizinan. Hal lain adalah perizinan dapat diupayakan cepat diterbitkan ketika tidak ada lagi permasalahan teknis dengan instansi terkait, contohnya: ketika pemohon perizinan mengurus IMB (Izin Mendirikan Bangunan) maka harus mendapat lampu hijau dari Dinas PU Kota Gorontalo. Hal inilah yang dikeluhkan oleh masyarakat bahwa pelayanan DPM-PTSP itu berbelitbelit. Tetapi peneliti menilai hal ini wajar dilakukan karena struktur pelaksanaan organisasi birokrasi harus mengutamakan yang namanya regulasi. Ketika regulasi tidak dijalankan atau bahkan dipangkas prosesnya maka akan terdapat unsur kesalahan administratif yang ditujukan kepada DPM-PTSP sehingga akan sangat merugikan pegawai didalamnya.

Sangkala, A. A., Lengkong, F. D., \& Tampi, G. B. (2018) dalam artikelnya mengatakan bahwa profesionalisme aparatur pemerintah mempunyai hubungan yang positif dan signifikan dengan kualitas pelayanan publik serta berhubungan secara kontributif. Artinya bahwa meningkat atau menurunnya kualitas pelayanan publik turut ditentukan oleh profesionalisme yang 
dimiliki aparatur dalam melaksanakan tugas pelayanan publik.

Selanjutnya penulis melihat DPMPTSP Kota Gorontalo sudah mengarah pada layanan berbasis aplikasi $e$ government bernama aplikasi Si Cantik, akan tetapi pada pelaksanaanya peneliti menilai aplikasi ini belum cukup optimal untuk dijalankan karena disamping fiturnya belum lengkap, aplikasi tersebut belum cukup dikenal oleh masyarakat sehingga pemohon perizinan lebih memilih mengurus langsung dikantor ketimbang berkonsultasi langsung via aplikasi.

Untuk memperbaiki sistem birokrasi pada DPM-PTSP penulis menekankan optimalisasi jalur komando dalam artian perbaikan kinerja melalui sentuhansentuhan kepemimpinan mulai dari Kepala Bagian, Kepala Bidang, sampai dengan Kepala Dinas. aspek kepemimpinan yang peneliti masukkan sebagai bagian dari proses pengorganisasian didasarkan atas berbagai pertimbangan dan hasil temuan penelitian bahwa kepemimpinan merupakan jawaban atas segala perbaikan dari manajeman pelayanan publik dari organisasi DPM-PTSP. Menurut pandangan penulis hal tersebut karena pengaruh besar dari sosok pimpinan mulai dari Kepala Seksi, Kepala Bagian, Kepala Bidang, Sekretaris Dinas, dan tentu saja pengaruh paling besar ada pada Kepala Dinas DPM-PTSP Kota Gorontalo.

Penulis berpendapat bahwa kepemimpinan menjadi bagian penting dari salah satu fungsi manajeman dalam penataan organisasi birokrasi. Hal ini berarti bahwa kemampuan yang dimiliki oleh seorang pimpinan secara psikologis pasti akan berusaha berpikir dan berperilaku jauh lebih kedepan dibanding dengan bawahannya. Oleh sebab itu pimpinan akan memberikan tindakan yang dapat menimbulkan aktivitas pada bawahannya. Pimpinan dapat mengarahkan dan mempengaruhi para bawahan yakni Kepala Bidang, Kepala Bagian, Kepala Seksi, Staf Pegawai dan Petugas front office yang ada di DPM-PTSP Kota Gorontalo untuk bagaimana melakukan tugas-tugas yang esensial. Dengan menciptakan suasana yang tepat, pengaruh dari pimpinan akan membantu para bawahannya untuk dapat bekerja sebaikbaiknya. Kepemimpinan termasuk didalamnya penggerakan (actuating) yaitu melakukan pergerakan dalam memberikan motivasi kepada bawahan untuk melakukan tugas-tugasnya. Hubungannya dengan manajeman pelayanan publik adalah bahwa manajeman merupakan suatu ruang lingkup yang mencakup kepemimpinan dan dapat menciptakan iklim organisasi yang kondusif serta terarah. Hal tersebut sebagaimana yang didalami oleh peneliti tentang bagaimana perubahan yang dilakukan oleh DPMPTSP Kota Gorontalo sejak adanya perubahan Kepala Dinas pada awal tahun 2017 menjadikan perkembangan kantor ini menitik beratkan pada manajeman organisasi serta perbaikan alur pelayanan dalam melayani pemohon perizinan dan non perizinan.

Pemerintah dan masyarakat memiliki peran yang sama dalam mengelola lembaga negara melalui reformasi birokrasi, untuk membangun pola perbaikan secara bersama dengan prinsipprinsip keadilan dan kebaikan. Perkembangan reformasi birokrasi menunjukkan bahwa pelayanan publik masih lemah. Hal ini dipengaruhi oleh struktur birokrasi yang gemuk dan jumlah pegawai yang berlebih, sehingga terjadi tumpang tindih fungsi dan wewenang. Tingginya angka Korupsi, Kolusi dan Nepotisme (KKN) yang dilakukan oleh oknum birokrat juga menjadi pemicu 
lambannya pencapaian tujuan reformasi birokrasi. Peran pemimpin juga berpengaruh terhadap lemahnya kinerja birokrasi diberbagai tingkatan dan level. Sementara itu, pemimpin yang kompeten dan profesional belum banyak. Masih berkembangnya model patrimonialisme (dimana pemimpin harus dilayani dan bukan melayani, memunculkan pegawai yang bekerja atas dasar keinginan pemimpin dan bukan kesadaran dari dalam dirinya), akan berdampak terhadap lemahnya pelayanan. Peran pemimpin sebagai agen perubahan yaitu harus mampu mengembalikan kepercayaan masyarakat terhadap manajemen dan pengelolaan birokrasi. Peran ini dilakukan melalui transparansi, akuntabilitas, kompetensi, dan kualitas sumber daya manusia yang dimilikinya. Kepemimpinan seperti ini bertujuan menciptakan organisasi birokrasi yang adil dan baik sebagai aktualisasi pemimpin dalam penguatan kapasitas lembaga negara terhadap tujuan pemerintahan, yaitu good governance.

Fungsi kepemimpinan menurut Nawawi (2013), bahwa fungsi kepemmpinan yaitu sebagai berikut: 1) Fungsi instruktif, adalah pemimpin sebagai komunikator yang menentukan apa (isi perintah) dan bagaimana (cara mengerjakan perintah), bilamana (waktu memulai, melaksanakan, dan melaporkan hasilnya), dan dimana (tempat mengerjakan perintah) agar keputusan dapat diwujutkan secara efektif. Sehingga fungsi orang yang memimpin hanyalah melaksanakan suatu perintah; 2) Fungsi konsultatif, adalah pemimpin menggunakan konsultatif sebagai bentuk dari komunikasi dua arah untuk usaha menetapkan keputusan yang membutuhkan pertimbangan dan konsultasi dengan orang yang dipimpinnya; 3) Fungsi partisipasi, adalah pemimpin dapat mengaktifkan anggotanya dalam pengambulan keputusan maupun melaksanakannya; 4) Fungsi delegasi adalah pemimpin memberikan pelimpahan wewenang yang membuat sampai dengan menetapkan keputusan. Fungsi delegasi merupakan kepercayaan secorang pemimpun kepada seorang yang diberikan pelimpahan wewenang untuk bertanggung jawab; 4) Fungsi pengendalian, adalah pemimpin dapat membimbing, mengarahkan, koordinasi dan pengawasan terhadap aktivitas anggotanya.

Berdasarkan definisi kepemimpinan secara umum diatas maka penulis berpendapat bahwa gaya kepemimpinan yang cocok diterapkan pada DPM-PTSP Kota Gorontalo adalah kepemimpinan transfprmasional. Bass dan Avolio, (1994) Dengan bahasa sederhana, kepemimpinan transformasional dapat didefinisikan dan dipahami sebagai kepemimpinan yang mampu mendatangkan perubahan di dalam diri setiap individu yang terlibat atau bagi seluruh organisasi untuk mencapai performa yang semakin tinggi. Lebih lanjut Burns (1978) dalam buku Sutikno (2014) berpandangan bahwa kepemimpinan transformasional sebagai sebuah proses dimana "para pemimpin dan pengikut saling menaikkan diri ke tingkat moralitas dan motivasi yang lebih tinggi”. Menurut Burns, kepemimpinan transformasional dapat diperlihatkan oleh siapa saja dalam organisasi pada jenis posisi apa saja. Karakteristik utama kepemimpinan transformasional ini diantaranya memiliki kemampuuan untuk bertindak sebagai agen perubahan (agent of change) bagi organisasi, sehingga dapat menciptakan strategi-strategi baru dalam mengembangkan praktik-praktik organisasi yang relevan. Burns (1978) menyatakan bahwa model kepemimpinan transformasional ada hakekatnya menekan seorang pemimpin perlu memotivai para Copyright (c) 2020, Publik (Jurnal Ilmu Administrasi), ISSN: 2301-573X (Print), ISSN: 2581-2084 (Online) 
bawahannya bertanggung jawab lebih dari yang diharapkan. Pemimpin transformasional harus mampu mendefinisikan, mengkomunikasikan, mengartikulasikan visi organisasi, dan bawahan harus menerima kredibilitas pemimpinnya.

Mustaqiem, M. (2010) Dalam Artikel Jurnalnya "Profesionalisme Pegawai Negeri Sipil Dalam Pelayanan Publik" Civil Service Journal, 4(2 November) menegaskan bahwa aparat negara (pegawai negeri sipil) sangat dimungkinkan dapat memberikan pelayanan kepada masyarakat (publik) secara profesional sepanjang memiliki komitmen untuk itu dan profesionalisme selalu terjaga. oleh karena pelayanan kepada masyarakat dilakukan terus menerus sepanjang waktu dan dalam berbagai bidang atau sektor, maka selain peningkatan pendidikan dan pelatihan; perlu dilakukan inovasi materi pendidikan dan pelatihan, pengawasan, evaluasi, maupun survei tentang pelayanan masyarakat dengan responden anggota masyarakat.

Dari hasil uraian tentang kepemimpinan trasformasional menurut ahli diatas, maka penulis berpandangan bahwa dengan penerapan gaya kepemimpinan transformasional mulai dari Kepala Dinas, Kapala Bidang, Kepala Bagian, Sampai Kepala Seksi di DPMPTSP sebagai pemimpin yang mempunyai kekuatan untuk mempengaruhi bawahan dengan cara-cara tertentu. Dengan penerapan kepemimpinan transformasional bawahan akan merasa dipercaya, dihargai, loyal dan respek kepada pimpinannya. Pada akhirnya bawahan akan termotivasi untuk melakukan lebih dari yang diharapkan. Dengan kata lain, faktor kepemimpinan dapat melakukan penataan berupa kemampuan mempengaruhi tingkah laku orang lain dalam situasi tertentu agar bersedia bekerja sama untuk mencapai tujuan yang telah ditetapkan. Hanya saja yang perlu diketahui bahwa cara pemimpin mempengaruhi bawahan dapat berbedabeda, misalnya memberikan gambaran masa depan yang lebih baik, memberikan perintah, melimpahkan wewenang, mempercayai bawahan, memberi penghargaan, memberi kedudukan, memberi tugas dan tanggung jawab, memberi kesempatan mewakili, mengajak, membujuk, meminta saran dan pendapat, memberikan motivasi, mendidik menciptakan perubaham, menegakkan disiplin, dan lain-lain.

Dengan demikian kepemimpinan adalah salah satu dari fungsi manajeman sehingga pengaruh pimpinan sangat penting dalam kegiatan organisasi birokrasi. Penulis berpendapat bahwa terdapat tiga imlikasi yang terkandung dari kepemimpinan yaitu: 1) Kepemimpinan menyangkut orang lain/bawahan atau pengikut; 2) Kepemimpinan menyangkut suatu pembagian kewenangan dari tiap-tiap individu pegawai; 3) Pimpinan dapat menggunakan pengaruh atau dapat mempengaruhi bawahan agar melaksanakan perintahnya.

Berdasarkan pembahasan yang telah diuraikan maka melalui peran pimpinan penulis berharap adanya area perubahan pada Dinas Penanaman Modal Dan Pelayanan Terpadu Satu Pintu Kota Gorontalo dapat diukur melalui 1) Mental Aparatur; 2) Pengawasan pimpinan; 3) Akuntabilitas kinerja; 4) Standar Operasional Prosedur; dan 5) Budaya kerja aparatur. Mengingat urgensitas perean aparatur dalam menyelenggarakan peran dan fungsinya, maka penulis berpendapat kiranya unsur pimpinan pada DPM-PTSP Kota Gorontalo dapat merumuskan pendekatan strategis untuk 


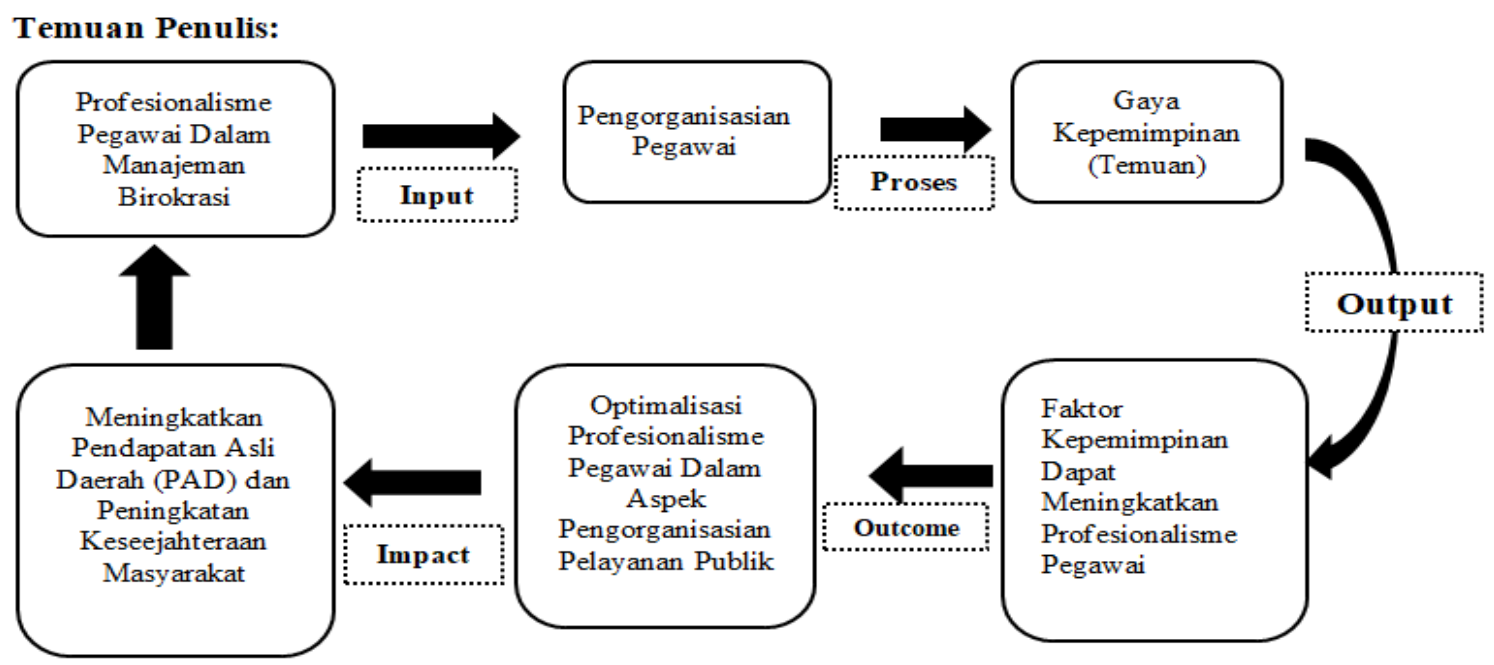

\section{Gambar 1}

Temuan mengenai urgensi Profesionalisme Pegawai Dalam Manajemen Birokrasi

membangun wajah baru aparatur yang professional, handal, tanggap, inovatif, dan fleksibel dan menjadi fasilitator yang dapat diandalkan oleh masyarakat pengguna layanan (Gambar 1).

Usman, J. (2011) mengatakan bahwa Manajemen profesional pelayanan publik harus lebih berorientasi pada tujuan paradigma pemerintahan yang didasarkan pada pendekatan manajemen baru, baik secara teori maupun praktis. Secara bersamaan, paradigma dari tujuan pemerintahan diharapkan dapat menghilangkan praktek bahwa birokrasi Weberian adalah negatif seperti struktur birokrasi hierarkhikal yang menghasilkan biaya operasional lebih mahal (ekonomi biaya tinggi) daripada manfaat yang diperoleh, prevalensi birokrasi, kurangnya inisiatif dan kreativitas aparatur, pertumbuhan mediokratis budaya dan inefisiensi. Oleh karena itu, institusi pelayanan publik dapat dilakukan oleh pemerintah dan organisasi non-pemerintah. Jika pemerintah, organisasi birokrasi pemerintah adalah garis depan organisasi (jalan birokrasi tingkat) terkait dengan pelayanan publik.

\section{PENUTUP}

\section{Kesimpulan}

Berdasarkan hasil dan pembahasan pada artikel ini menunjukkan bahwa kecenderungan aparat kurang profesional dalam menjalankan tugas dan fungsinya antara lain disebabkan oleh rendahnya motivasi untuk melakukan perubahan dan berinovasi. Aparat cenderung enggan melakukan perubahan dikenakan kurangnya dorongan dari pimpinan. Dalam mewujudkan aparat yang profesional, akuntabel, dan transparan maka dibutuhkan peran pemimpin sebagai pengarah dan memiliki jiwa dan pandangan yang visioner pada Dinas Penanaman Modal Dan Pelayanan Terpadu Satu Pintu Kota Gorontalo. Langkah-langkah konkrit pemimpin dalam menciptakan iklim demokrasi dimana bawahan disertakan dalam setiap pengambilan kebijakan yang berkaitan dengan peningkatan kinerja organisasi serta membangun komunikasi dua arah dalam setiap kegiatan akan membuat bawahan merasa dirinya adalah bagian penting dalam organisasi. Sikap pemimpin untuk menumbuhkan jiwa responsif pada setiap pegawai dapat

Copyright @ 2020, Publik (Jurnal Ilmu Administrasi), ISSN: 2301-573X (Print), ISSN: 2581-2084 (Online) 
meningkatan kualitas pelayanan perizinan dan non perizinan di Kota Gorontalo

\section{Saran}

Upaya yang dapat dilakukan untuk menumbuhkan profesionalisme aparatur adalah dengan membuat program kerja jangka Panjang, jangka menengah, dan jangka pendek serta menetapkan skala prioritas dalam setiap kegiatan yang bertujuan meningkatkan kualitas pelayanan publik.

Adapun penguatan aspek kepemimpinan sebagai rekomendasi dalam artikel ini adalah sebagai berikut: 1) Pengaturan kerja, bahwa dengan peran kepemimpinan maka pengaturan kerja dalam organisasi akan semakin tertata dengan baik, efektif dan efisien; 2) meningkatkan efektivitas kerja demi kepentingan Bersama. Bahwa eksistensi dari organisasi akan semakin meningkat apabila semua pihak yang ada didalam organisasi akan saling bahu membahu menciptakan lingkungan kerja yang baik dan mengarah pada tujuan dan cita-cita yang lebih baik; 3) Sinkronisasi tujuan. Bahwa fungsi komunikasi dan konsolidasi dalam organisasi harus terus dioptimalkan, maka peran pimpinan akan sangat dibutuhkan.

\section{DAFTAR PUSTAKA}

Arief Jauhari. (2015). Birokrasi Dalam Kerangka e-Government. Jurnal Magister Akuntansi. ISSN 2302-0164

Bass, B.M. and Avolio, B.J., (1994), Improving Organizational Effectiveness through Transformational Leadership, Sage, Thousand Oaks.

Burns, J.M. (1978). Leadership. New York
Hasibuan, M. (2001). Manajeman Sumber Daya Manusia. Jakarta: Bumi Aksara,

Henny Juliani. (2019). Perubahan perilaku aparatur sebagai model dalam mewujudkan reformasi birokrasi yang berkualitas. Adminitrative Law \& Governance Journal. Volume 2 (1)

Miles, B. Mathew dan Michael Huberman. (1992). Analisis Data Kualitatif Buku Sumber Tentang Metode-metode Baru. Jakarta: UIP.

Moeljono, Djokosantoso. (2003). Budaya Korporat dan Keunggulan. Korporasi. Jakarta: PT. Elex Media

Mustaqiem, M. (2010). Profesionalisme Pegawai Negeri Sipil Dalam Pelayanan Publik. Civil Service Journal, 4(2 November).

Nawawi, Ismail. (2013). Budaya organisasi kepemimpinan dan Kinerja. Jakarta: PT. Fajar Iterpratama Mandiri.

Peraturan Presiden Nomor 81 Tahun 2010 tentang Grand Design Reformasi Birokrasi 2010-2025

Peraturan Menpan RB Nomor 11 Tahun 2015 Tentang Road Map Reformasi Birokrasi 2015-2019

Sangkala, A. A., Lengkong, F. D., \& Tampi, G. B. (2018). Profesionalisme Aparatur Sipil Negara Dalam Penyelenggaraan Pelayanan Publik Di Kantor Kecamatan Singkil Kota Manado. Jurnal Administrasi Publik, 4(64).

Sutikno Sobry M. (2014). Pemimpin Dan Gaya Kepemimpinan. Edisi Pertama. Lombok. Holistica

: Harper \& Row. 
Siagian, P. S. (2002). Kepemimpinan organisasi \& perilaku administrasi. Jakarta: Penerbit Gunung Agung.

Usman, J. (2011). Manajemen Birokrasi Profesional dalam Meningkatkan Pelayanan Publik. Otoritas: Jurnal Ilmu Pemerintahan, 1(2). DOI: https://doi.org/10.26618/ojip.v1 $\underline{\mathrm{i} 2.24}$ 